\title{
Influences of Cost Factors Affecting Technical Performance of Local Government Projects in Nigeria: A Partial Least Square-Structural Equation Modeling (PLS-SEM) Approach
}

\author{
"Nuru Gambo', llias Said² and Radzi Ismail2
}

Published online: 31 July 2016

To cite this article: Nuru Gambo, Ilias Said and Radzi Ismail. (2016). Influences of cost factors affecting technical performance of local government projects in Nigeria: A partial least square-structural equation modeling (PLS-SEM) approach. Journal of Construction in Developing Countries, 21 (1): 85-111. doi: 10.21315/jcdc2016.21.1.5

To link to this article: $\mathrm{http}: / / \mathrm{dx}$.doi.org/10.21315/jcdc2016.21.1.5

Abstract: The technical performance requirements of projects posed a challenge to the sustainable development of small size local government projects particularly in developing countries. Studies in the past focused mainly on the performance of major foreign construction firms mostly owned and operated by expatriates. Very few researches however, have been conducted to assess the relationship between major cost factors affecting technical performance of small size local government projects. This study is aimed at assessing the relationship between major cost factors that affect technical performance of small size local government projects in Nigeria. Survey instruments were administered to major stakeholders in the construction industry comprising of project clients, contractors and consultants using proportionate stratified random sampling method. A Warp partial least square-structural equation modeling (PLS-SEM) software algorithm was used for the analysis of collected data. The software is one of the powerful software for data analysis and has an advantage of providing $p$ values based on the structure of the research model. The study concluded that cash flow problem, fraudulent practice and nature of construction environment are the major factors affecting technical performance of local government projects in Nigeria and further recommended the use of mediator variables like pay for performance and advance payment policy to minimise such negative effects. Governments in developing countries should devise a good cash flow policy and impose stringent penalties against any party involved in fraudulent activity.

Keywords: Cost, Factors, Technical, Performance, Projects, Nigeria

\section{INTRODUCTION}

The success of any construction project is realised when a project is built on targeted cost, time and quality with minimum conflicts. For a project to be successful the stakeholders need to ensure that the project is operating as efficiently and effectively as possible. Improving the efficiency and effectiveness of any project requires understanding of cost factors that influence practical approach or technical performance in implementing processes affecting the project. For improved technical performance, all relevant cost factors affecting technical performance of small scale local government projects should be

'Department of Quantity Surveying, Abubakar Tafawa Balewa University Bauchi, NIGERIA

2Project Management Department, School of Housing, Building and Planning, Universiti Sains Malaysia (USM), Pulau Pinang, MALAYSIA

"Corresponding author: gambonuru@yahoo.com

(C) Penerbit Universiti Sains Malaysia, 2016 
identified and regularly evaluated against key technical performance indicators of any project i.e. specification and quality.

Technical performance is defined as the totality of features required by a project or service to satisfy a given specification, need or fitness for purpose (Ali et al., 2010; Chan and Chan, 2004). Technical performance is the project guarantee that convinced both the client and the end-users that the specification was adhered to during construction. The meeting of required specification is one way to achieve project technical performance and specification is defined as workmanship guidelines provided to contractors so as to achieve technical quality of the project (Doloi et al., 2012; Songer and Molenaar, 1997). The aim of technical specification is to ensure that the technical requirements specified are achieved and is provided to ensure that products are built in good standards and according to proper procedures (Mortimer and Mortimer, 2015). Agostini et al. (2015) grouped technical specification under the quality category of a product and is expressed as that which determines the level of performance of individual units. Technical specification is subdivided into:

1. Individual unit specification which states boundaries of a unit's performance as a nominal value and tolerance.

2. Acceptable quality which states limits those are to be satisfied by most of the units (Agostini et al., 2015).

Previous studies in the area of technical performance are delimited to the provision of insight into the design parameters of the projects by benchmarking specific design elements of a project to achieve enhanced technical performance of a project. Factors that affect technical performance of projects were not considered in attempting to improve technical performance of projects. Identifying and assessing the impact of constructs that contribute to poor technical performance of small size local government projects (SSLGP) is one major step in improving technical performance of small scale local government projects. For instance, in Malaysia, the performance of small size projects are often characterised by improper selection of the right plant and equipment required for the construction or installation works. The contractors rent plant and equipment when required and at times these plant and equipment are scarce particularly during peak period of construction activities (Sambasivan and Soon, 2007). Moreover, the plant and equipment are usually not properly maintained (Winch 2010; Sambasivan and Soon, 2007). Mistakes in setting out of works at initial construction stage, inadequate contractor experience and frequent failure of construction plant and equipment are the main factors contributing to the poor technical performance of small size local government projects (Sambasivan and Soon, 2007). In a similar finding in Malaysia, Memon et al. (2010) supported the previous findings that contractor inexperience and inadequate experience of labour are the major factors contributing to poor technical performance of small size local government projects in developing countries. Skill and technical competence of contractor's workforce, contractor's ability to identify and mitigate technical and schedule/programme risks, contractor's compliance with technical requirements are the major factors identified as having negative influence on the technical performance of projects in Iran and Ghana (Jafari, 2013; Frimpong, Oluwoye and Crawford, 2003). However, in Vietnam, LuU, Kim and Huynh (2008) 
argued that the inability of the firms to recruit and retain qualified technical staff, inaccurate detailed working drawings and lack of good cooperation among the parties involved in construction activities are the main factors contributing to projects' poor technical performance. This view was supported by Doloi, lyer and Sawhney (2011) in India, that the inability of contractors' to proactively respond to changes in technical direction influence their technical performance. Technical performance of a facility extends to its functionality, which must fulfill the intended function, user expectation and participants' satisfaction (Mohit, Ibrahim and Rashid, 2010; Chan and Chan, 2004). In Nigeria, Ogwueleka (2011) described that the inability of small size contractors to respond to the technical innovation was the major factor affecting technical performance of projects. Likewise the issue of cost factors affecting technical performance of projects occurs not only in developing countries but also in developed countries like United States of America (USA) and the United Kingdom (UK). In USA, Mahesh (2012) found that various factors were responsible for poor technical productivity of small size projects as a result of both cost and time factors. The identified factors were external, financial, managerial and miscellaneous. In UK, the technical performance of small size projects was criticised for under performance as compared to other industries in the UK. In comparing technical performance of contractors in Japan, United Kingdom and United States, the Japanese contractors completed projects mostly with very minor defects and provided more time for defects liability period. The contractors were less often called back for rework compared to contractors from UK and USA that seek regular feedback on defects from project clients. The superior technical performance of Japanese contractors against their American and UK counterparts was due to quality consciousness, advance quality management and quality assurance (Xiao and Proverbs, 2002). Generally, the UK construction industry is criticised for not performing at the same level with other developed countries (Takim and Akintoye, 2002). Furthermore, in the UK, Kurul, Zhou and Keivani (2013) suggested integrating cost into the technical aspects of project performance to balance the socio-economic performance of the projects.

Cost factors refers to the main research independent constructs that affect the dependent construct (technical performance) of construction projects in one hand and overall performance of contractors in the other. Cost factors are the factors that have a direct proportional cost relationship with the technical performance of SSLGPs (Gambo and Said, 2014; Ezeh, 2013). Cost factors affecting technical performance of SSLGPs are the cost-related factors that lead to cost overrun and followed by poor quality delivery of projects. The constructs includes: cash flow problem, effects of fraudulent practice and nature of construction environment. These are referred to as main or major cost factors because mostly all other sub-factors were in one way or other related to one or some of these factors (Matthew, Patrick and Denise, 2013; Odeyinka, Lowe and Kaka, 2008). Cash flow problem is a situation where a contractor does not have enough cash to be able to pay the firm's liabilities. The main causes of cash flow problem are: low profits, underpayment for approved valued works, client insolvency and delays in payment (Odeyinka, Lowe and Kaka, 2008; Wasi and Skitmore, 2001). The second construct is the effects of fraudulent practice is any action or omission, including misrepresentation that knowingly or recklessly misleads, or attempt to mislead any party in a contract to obtain a financial benefit or to avoid an 
obligation. The factors that affect technical performance of SSLGPS under fraudulent practice are: actions not taken against contractor's non-compliance with the terms and condition of contract, double payment for the same item, substitution of specified item with used or inferior ones, and expenses paid when not incurred (Matthew, Patrick and Denise, 2013). The third construct is effects of the nature of construction environments. Construction environment is the natural environment in the process of change by human efforts through constructions of dwellings, landscaping and heating and/or cooling to control indoor climate. The nature of construction environment affects most construction materials, plants and equipment, as well as procedures or processes of construction and overall technical performance of the facilities. The following factors are listed under natural environmental factors affecting the technical performance of projects: metrological trends like storms, geological process like soil and strata characteristics and long term environmental trends like climate change, presence of surface water etc.

This study is aimed at:

1. Identifying major cost factors affecting technical performance of projects.

2. Assessing the relationship between the cost factors that affect technical performance.

\section{FACTORS INFLUENCING TECHNICAL PERFORMANCE OF SSLGP}

The independent constructs that are identified to have an effects on the technical performance of small size local government projects are: cash flow problem, fraudulent practice and nature of construction environment (Hazir, Haouari and Erel, 2015; Inuwa, Usman and Dantong, 2015; Qu et al., 2015; Gambo and Said, 2014; Ezeh, 2013; Local Government Monitoring and Evaluation Committee [LGMEC], 2009).

Hazir, Haouari and Erel (2015) stated that cash flow problem is the main factor contributing to time delays which leads to poor quality of products. Poor quality of products in turn, leads to its poor technical performance. Liang and Gan (2015) added that poor cash flow policy is the major factor associated with the poor technical performance of small size projects. Small construction businesses usually do not have adequate fund to finance projects, the business normally depends on the progress payments to run its daily activities such as procurements of plant and equipment, recruitment and training of staff. Any delay in payment affects daily running of the business and hence leads to poor technical performance of product. Cash flow problem have devastating effects on the technical aspect of the performance of small size projects particularly in developing countries where small scale contractors have difficulties in accessing bank loans, overdrafts and invoice financing because of persistence of insolvency in the industry (Addo, 2015). Cash flow problem is a situation where a contractor does not have enough cash to be able to pay all the business liabilities. Adequate cash flow is essential to keep a project afloat, but the problems are that small size projects in developing countries are bedeviled by a number of cash flow problems. A survey conducted by Asian Review on small size projects in 2010, found that $50 \%$ of the projects had cash flow problems (Russell, 2010). The 
contractors of those projects often consider bandaging their cash flow problems with temporary cash infusions, but a project ultimately needs to fix structural problems in their supply chain to show qualitative output. Russell (2010) stated that cash flow problem is an indication that a project consumed more money than budgeted cost due to non-conformance with the firm's financial statement, resulting in low quality output and low investment into the procurement of new sophisticated tools, plant and equipment for fulfilling the required technical performance.

Cash flow is viewed generally in construction projects in two ways. Firstly, cash flow as the net receipt or net disbursement resulting from receipts and disbursements occurring in the same period as presented in Equation 1 (Odeyinka, Lowe and Kaka, 2008).

$$
\text { Cash flow }=\text { Receipts }- \text { Disbursements }
$$

Equation 1 indicates that a positive cash flow shows a net receipt in a particular period of interest, while a negative cash flow shows a net disbursement in that period. Secondly, cash flow is defined here as the actual movement or transfer of cash (money) into or out of a firm (Odeyinka, Lowe and Kaka, 2008). Therefore, based on this definition, money coming to the firm is termed as positive cash flow because the money is credited to the account of the firm and money going out from the firm is termed negative cash flow because the money is debited from the account of the firm, so the difference between the two is termed net cash flow.

Net cash flow $=$ Positive cash flow (Cash in) - Negative cash flow (Cash out) Eq. 2

Based on the above definitions positive cash flow is derived from the monies or payment received by a firm during a period of time and negative cash flow is the monies expended on a contract for the procurements of materials, plant, equipment, services, wages and salaries and other overhead costs (Odeyinka, Lowe and Kaka, 2008). Memon et al. (2010) said that the effects of cash flow problems and financial difficulties in the Malaysian construction industry were the main significant factors affecting construction costs. Construction cost problems invariably lead to technical difficulties. Cash flows are predicted to suffer more severely from timing and matching problems that reduce their ability to reflect the firm's technical performance: therefore, cash flow problem seriously affects the technical performance of projects (Liang and Gan, 2015). The factors under cash flow problems include delay in settling claims and agreeing on variations/day works, under valuation of performed works, clients' insolvency and delays in payments of approved valued works (Gambo and llias, 2014; Odeyinka, Lowe and Kaka, 2008).

In Australia, Brown et al. (2015) identified that fraudulent practice in the construction industry was the major factor affecting technical performance of projects. Fraudulent practice leads to total collapsed of any business and the industry in general (Inuwa, Usman and Dantong, 2015). In Nigeria, fraudulent practice affects technical performance of construction projects in various ways which includes: deliberates substitution of specified construction material with less quality ones, improper social contact between contractors and consultants and 
problems of kickbacks (Inuwa, Usman and Dantong, 2015). Elinwa and Buba (1993) stated that fraudulent practices and kickbacks were the most important factors leading to poor technical performance of projects in the Nigerian construction industry. Stevens and Fuentes-George (2015) mentioned that all government-funded projects in developing countries were political in nature. Political problems, in turn, invariably lead to poor cash flow problems, bribery and corruption. Matthew, Patrick and Denise (2013) defined fraudulent practice as intent to deceive through false representation of a matter or a fact, whether by word or by conduct, or by concealment of information, which should have been disclosed, in order to cause damage to an entity relying upon that false information. The factors that affect technical performance of projects under fraudulent practices are: action not taken against contractor's non-compliance with the terms and conditions of contract, double payments for the same item, substitution of specified items with used or inferior ones, expenses paid when not incurred, falsification of contract documents and giving gratuity to induce a party to the contract to give unfair advantage (Kshetri, 2015; Samuel and Ovie, 2015; Matthew, Patrick and Denise, 2013).

Qu et al. (2015) stated that nature of construction environment affects technical performance of construction projects in a various ways such as high high humidity air reacts with cement and other metallic materials; this lowered the strength of construction materials. Ngacho and Das (2015) revealed that storm and other force majeure affects technical performance of construction projects. Whereas Vilanova, Filho and Balestieri (2015) described that high underground water is the major factor that affects the technical performance sub-base and base courses of road pavements and leads to its failure. The nature of construction environment affects the technical performance of projects, which has become a major issue to the public (Akanni, Oke and Akpomiemie, 2015). The factors affecting the nature of construction environments are: harsh construction sites, civil commotion/disturbances, topography of the construction/working site, site constraints and storage limitations, availability and supply of labour to the site, hostile political and economic environment, etc. (He et al., 2015). Polluted water recycling and reusing wastes were other factors having significant impacts on the technical performance of projects (Akanni, Oke and Akpomiemie, 2015). The effects of the nature of construction/working environments also have significant impact on the technical performance of small size projects particularly in rural areas (Oslo and Paris Conventions for the Protection of Marine Environments [OSPAR], 2008). The report further indicated that the effects have cumulative impact on the quality of products and further divided it into permanent and temporary effects. The permanent effects comprised of meteorological trends like storms, geological processes like soil and strata characteristics and long term environmental trend like climate change. The temporary effects comprised of chemical, biological and ecological effects, social and political conditions such as land use acts, development trends, regulations, social trends and public safety (OSPAR, 2008). The nature of construction/working environments affect not only the projects itself but the project site, used for project installation and materials such as concrete, timber, clay, sand, gravel, steel, etc. 


\section{RESEARCH METHOD}

This study is quantitative in nature: a questionnaire survey was administered to 550 contractors, project management consulting firms and project clients in the northern part of Nigeria. The region comprises of 19 states and federal capital territory Abuja. The region represents almost $80 \%$ of the total country's land mass $\left(744,249.08 \mathrm{~km}^{2}\right)$ and a population of about 95 million people (National Population Commission, 2000). A total of 387 and 357 questionnaires were returned and analysed respectively. Thirty questionnaires were rejected i.e. not included in the analysis because of discrepancies in the responses and/or majority of the items in the questionnaire were left unattended or unanswered. A Warp 3 PLS regression algorithm was used in the data analysis. The data were bootstrapped to 999 times from the original samples with replacement. Bootstrapping approach generated an empirical representation of the sampling distribution of the effect by treating the original sample size as a representation of the population in the miniature: this is repeatedly resample during analysis as a mean of copying the original sampling process (Hayes, 2009). The study recorded the overall return rate of $70 \%$ and response rate of $65 \%$ as against the researches of Mahesh (2012) with $21.17 \%$, Odeyinka, Lowe and Kaka (2008) with 52\% and Yasamis, Arditi and Mohammadi (2002) with $54 \%$.

\section{Measurement Model for the Research Constructs}

The reliability of the survey instrument indicated an extent to which the constructs or dimensions are without bias (free from error) and hence ensure consistencies of measurement across the various items in the instrument (Sekaran and Bougie, 2011). The composite reliability coefficients (CRC) and Cronbach's alpha (CA) for the latent variables in this study were presented in Table 2.

\section{Composite reliability}

Tables 2 presents the composites reliability coefficients for the latent variables; technical performance (tecper) had a CRC of 0.772 , then cash flow problem (casflo) had a CRC of 0.941 and the fraudulent practice had a CRC of 0.927 and lastly the composite reliability coefficient of the nature of construction environment (envfac) had a CRC of 0.717 which are regarded as excellent and acceptable (Sekaran and Bougie, 2011; Field, 2009; Pallant, 2010). The survey instruments are regarded as internally consistent.

\section{Cronbach's alpha}

Table 2 presents the CA coefficients for the latent variables: technical performance (tecper) had a CA of 0.761 , then cash flow problem (casflo) had a CA of 0.930 , and fraudulent practice (frapra) had a CA of 0.915 and lastly the effects of factors affecting construction environment (envfac) had a CA value of 0.730 all fall within the acceptable limit/bench mark of 0.70 and all regarded as excellent and acceptable according to Field (2009). CA of cash flow problems had a CA of 0.930 regarded as excellent and acceptable (Sekaran and Bougie, 
2011; Field, 2009; Pallant, 2010). This indicated that the survey instruments are regarded as reliable.

\section{Factor loading}

Table 2 presents the model factor loading. Individual factors under fraudulent practice had loadings between $0.466-0.767$ the minimum value was above the acceptable level of 0.4 and the maximum value above the preferred level of 0.7 (Hulland, 1999). Similarly, cash flow problem had a factor loading between 0.5460.865 the minimum value above the acceptable level of 0.4 and the maximum value above the preferred value of 0.7 (Hulland, 1999). The factor loadings in relation to the nature of construction environment had loadings between 0.43 0.880 with the minimum loading above the acceptable level of 0.4 and the maximum above the preferred level of 0.7 (Hulland, 1999).

\section{Average variance extracted (AVE)}

Table 2 presents the average variance extracted (AVE) for the research constructs. The effects of fraudulent practice had AVE value of 0.464 which is greater than the acceptable threshold of 0.4 , so the convergent validity is confirmed (Memon et al., 2013; Roldán and Sánchez-Franco, 2012; Bagozzi and Yi, 1988). The AVE in respect to the construct cash flow problem had an AVE of 0.619, which is greater than the acceptable level of 0.4 , so the convergent validity is confirmed (Memon et al., 2013; Roldán and Sánchez-Franco, 2012; Bagozzi and Yi, 1988). The AVE value in respect to the nature of construction environment had a value of 0.498 well above the acceptable value of 0.4 ; this confirmed the convergent validity (Memon et al., 2013; Roldán and Sánchez-Franco, 2012; Bagozzi and Yi, 1988). The AVE in respect to technical performance of small size local government projects in Nigeria had an AVE value of 0.576 well above the acceptable limit of 0.4 ; this confirmed the convergent validity on the technical performance (Memon et al., 2013; Roldán and Sánchez-Franco, 2012; Bagozzi and Yi, 1988).

\section{Measurement Scale for the Research Constructs}

The four research constructs i.e. technical performance of small size local government projects, cash flow problem, fraudulent practice and nature of construction environment were all measured using a five-point Likert scale. Likert scale is concerned with uni-dimensionality that makes sure all factors measure the same thing and is the most popular scaling procedure in use today (Giudici, 2003; Oppenheim, 2000). Technical performance of small size local government projects being the dependent construct was measured using a five-point Likert scale, with the scale defining the levels of technical performance of the projects ranging from very low performance to very high performance. Level of technical performance is described as the journey so far reached in achieving quality of products (Elger, 2008). The performance levels are defined by Team Leadership (2010) as follows:

1. Very low performance (Level 1) refers to unsatisfactory performance that does not meet all the requirement of job standards. 
2. Low performance (Level 2) implies performance that slightly or nearly meets some requirement of the job standards.

3. Average performance (Level 3) describes the performance that consistently meets the normal expectations of the work standards.

4. High performance (Level 4) indicates where the project consistently meets and frequently exceeds most expectations of the work standards.

5. Very high performance (Level 5) implies achievement in all aspects of responsibilities being consistently and substantially beyond expectations.

The independent construct, cost factors affecting technical performance of local government projects was also measured using a five-point Likert scale ranging from factors with no severe effects on the technical performance of the project to factors with extremely severe effects on the technical performance of projects (Amoah, Ahadzie and Dansoh, 2011; Oyewobi and Ogunsemi, 2010). The severity of the factors on the scale is described as follows:

1. No severe effects (Scale 1) described the factors that have no negative effects on the technical performance of small size projects.

2. Least severe effects (Scale 2) refer to factors that have little negative effects on the technical performance of small size projects.

3. Severe effects (Scale 3) refer to factors having moderate negative effects on the technical performance of the projects.

4. Very severe effects (Scale 4) refer to factors having large negative effects on the technical performance of the projects.

5. Extremely severe effects (Scale 5) refer to factors having disastrous effects on the technical performance of the projects.

\section{Content Validity}

Sekaran and Bougie (2011) stated that content validity is used in research to validate the research instruments used for a research study. Content validity is used to assess how well an idea or concept is represented by the items in a questionnaire. The content validity for this study was conducted by requesting experts in the field of construction and project management research and academics on the suitability of the items in the questionnaire. After thorough discussions the experts validated, verified and agreed on 10 items under cash flow problem, 15 items under fraudulent practice, and 10 items under nature of construction environment. The dependent variable technical performance of small size local government projects is divided into two major groups namely: individual specification and acceptable quality. The individual specification had a total of six items whereas acceptable quality had a total of 11 items as shown in the Table 3.

\section{Construct Validity}

Table 4 presents the construct validity for the research items and this was achieved using factor analysis. The factor analysis was carried out to test and identify problems associated with multi-collinearity and singularity in the survey instruments on the four major constructs namely: cash flow problem, fraudulent practice, 
nature of construction environment and technical performance of projects. The Kaiser-Meyer-Olkin measure of sampling adequacy in respect to cash flow problem (KMO) was 0.912, then the total variance explained was $65.903 \%$, the correlation matrix (R-matrix) was 0.01, and the chi-square, $X^{2}(357)=2487.882$ with $p=0.000$ significant at $p=0.05$ level of significance. The fraudulent practice had a $\mathrm{KMO}$ value of 0.873 , then the total variance explained was $64.083 \%$, and $R$-matrix was $0.04, X^{2}(357)=1921.244$ with $p=0.000$ significant at $p=0.05$ level of significance. The nature of construction environment had a $\mathrm{KMO}$ value of 0.893 , the total variance explained was $56.383 \%$, then $R$-matrix was 0.02 and $X^{2}(357)=$ 2128.405 and $p=0.000$ significant at $p=0.05$ level of significance. The technical performance of small size local government projects had a $\mathrm{KMO}$ value of 0.871 , the total variance explained was $64.265 \%$, then the $R$-matrix was 0.01 and $X^{2}$ (357) $=2354.766$ with $p=0.000$ significant at $p=0.05$ level of significance. This showed that all the four determinants of the $R$-matrix were greater than 0.0001 which indicated that there was no multi-collinearity or singularity among the construct items in the research instruments. Therefore, no single item was extracted from the research instrument due to either multi-collinearity or singularity (Field, 2009).

94/PENERBIT UNIVERSITI SAINS MALAYSIA 
Influences of Cost Factors Affecting Technical Performance

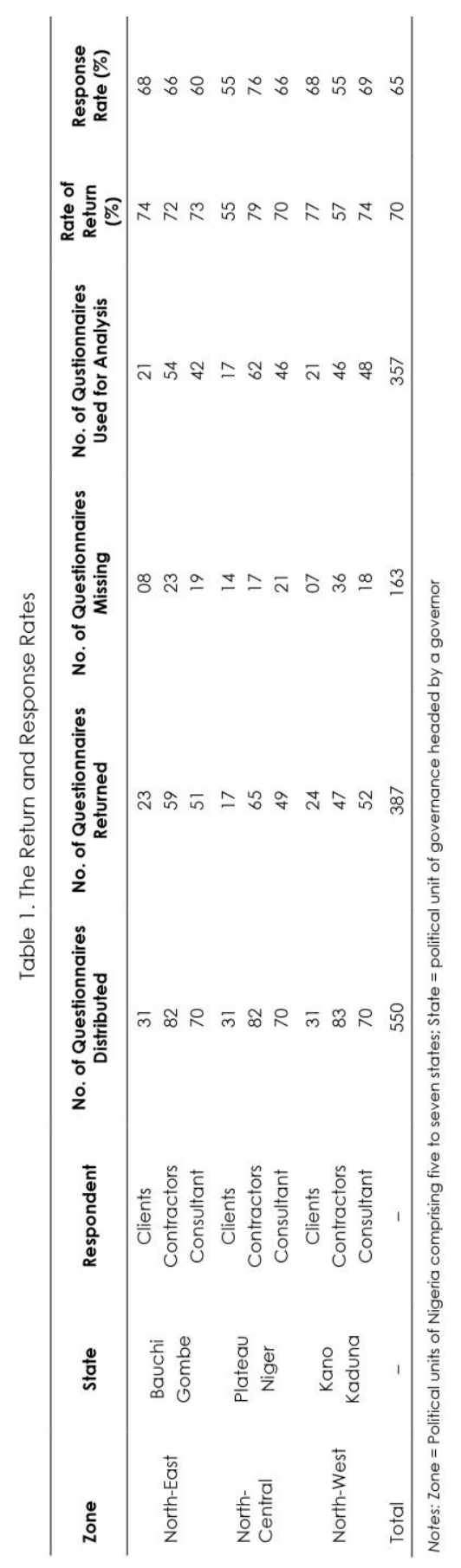

PENERBIT UNIVERSITI SAINS MALAYSIA/95 
Nuru Gambo, Ilias Said and Radzi Ismail

Table 2. Measurement Model for the Research Constructs

\begin{tabular}{|c|c|c|c|c|c|}
\hline $\begin{array}{l}\text { Model } \\
\text { Construct }\end{array}$ & $\begin{array}{c}\text { Measurement } \\
\text { Item }\end{array}$ & Factor Loading & CR & $\begin{array}{c}\text { Cronbach's } \\
\text { Alpha }\end{array}$ & AVE \\
\hline \multirow[t]{15}{*}{ Frapra } & Frapra 1 & 0.466 & 0.927 & 0.915 & 0.464 \\
\hline & Frapra 2 & 0.689 & & & \\
\hline & Frapra 3 & 0.511 & & & \\
\hline & Frapra 4 & 0.705 & & & \\
\hline & Frapra 5 & 0.767 & & & \\
\hline & Frapra 6 & 0.728 & & & \\
\hline & Frapra 7 & 0.713 & & & \\
\hline & Frapra 8 & 0.716 & & & \\
\hline & Frapra 9 & 0.737 & & & \\
\hline & Frapra 10 & 0.646 & & & \\
\hline & Frapra 11 & 0.696 & & & \\
\hline & Frapra 12 & 0.735 & & & \\
\hline & Frapra 13 & 0.727 & & & \\
\hline & Frapra 14 & 0.720 & & & \\
\hline & Frapra 15 & 0.577 & & & \\
\hline \multirow[t]{10}{*}{ Casflo } & Casflo 1 & 0.814 & 0.941 & 0.930 & 0.619 \\
\hline & Casflo 2 & 0.797 & & & \\
\hline & Casflo 3 & 0.844 & & & \\
\hline & Casflo 4 & 0.817 & & & \\
\hline & Casflo 5 & 0.865 & & & \\
\hline & Casflo 6 & 0.865 & & & \\
\hline & Casflo 7 & 0.787 & & & \\
\hline & Casflo 8 & 0.768 & & & \\
\hline & Casflo 9 & 0.714 & & & \\
\hline & Casflo 10 & 0.546 & & & \\
\hline \multirow[t]{10}{*}{ Envfac } & Envfac 1 & 0.493 & 0.717 & 0.730 & 0.498 \\
\hline & Envfac 2 & 0.431 & & & \\
\hline & Envfac 3 & 0.495 & & & \\
\hline & Envfac 4 & 0.436 & & & \\
\hline & Envfac 5 & 0.869 & & & \\
\hline & Envfac 6 & 0.830 & & & \\
\hline & Envfac 7 & 0.880 & & & \\
\hline & Envfac 8 & 0.856 & & & \\
\hline & Envfac 9 & 0.876 & & & \\
\hline & Envfac 10 & 0.809 & & & \\
\hline \multirow[t]{2}{*}{ Tecper } & Specification & 0.759 & 0.772 & 0.761 & 0.576 \\
\hline & Quality & 0.759 & & & \\
\hline
\end{tabular}

Notes: $\mathrm{CR}=$ Composite reliability; $\mathrm{AVE}=$ Average variance extracted 


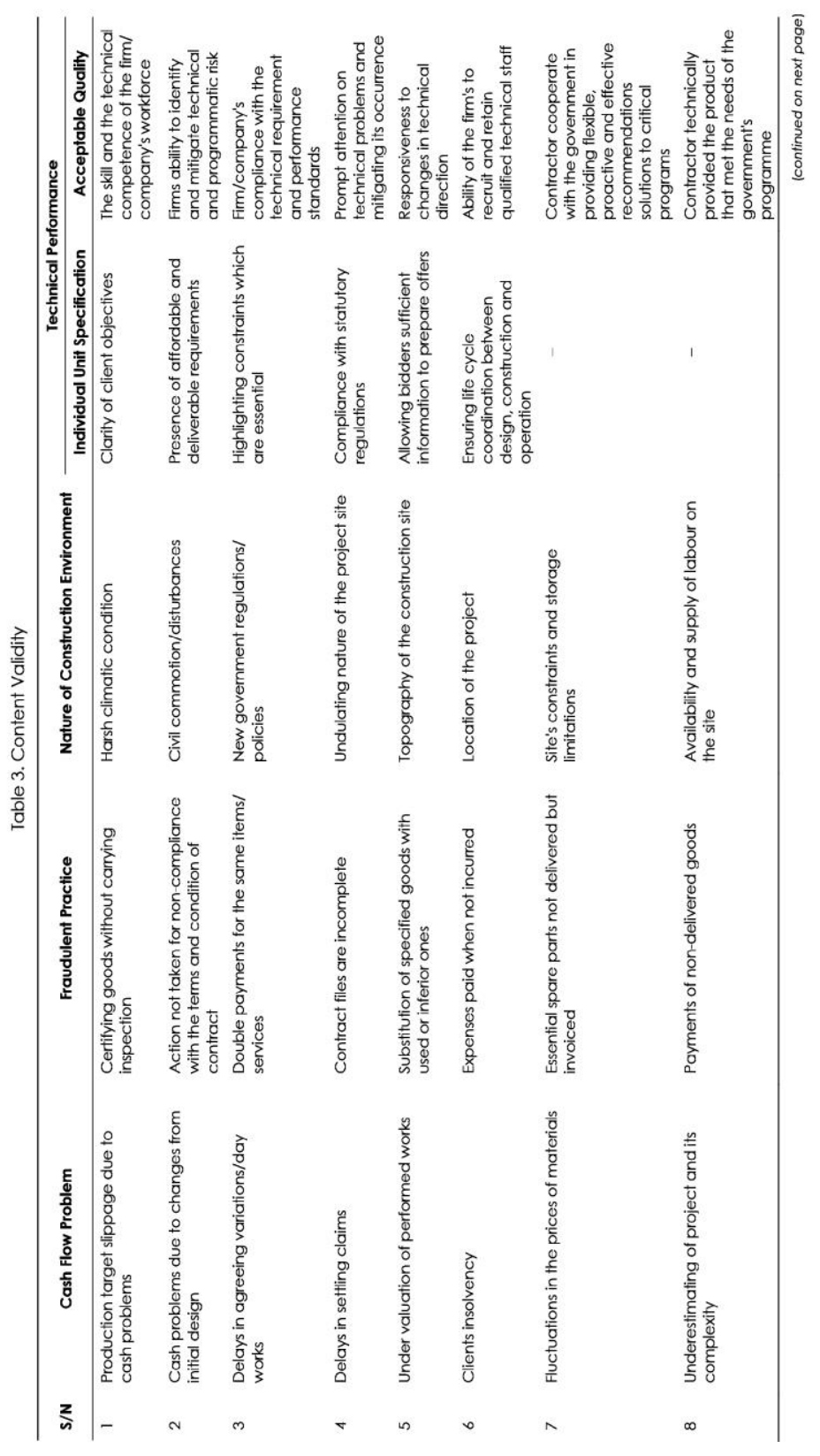

PENERBIT UNIVERSITI SAINS MALAYSIA/97 


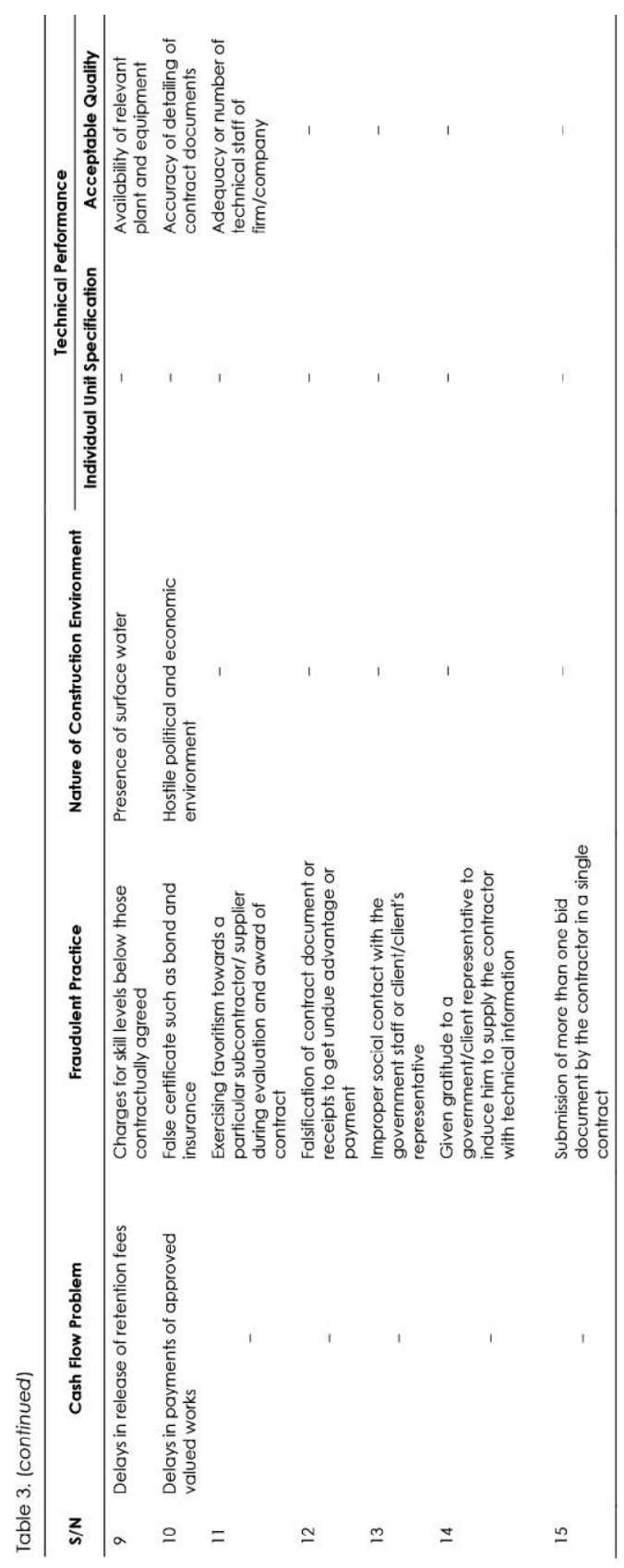

98/PENERBIT UNIVERSITI SAINS MALAYSIA 
Table 4. Constructs Validity

\begin{tabular}{lccccc}
\hline Construct & $\begin{array}{c}\text { Total Variance } \\
\text { Explained }\end{array}$ & R-Matrix & KMO & Chi-Square & P-Value \\
\hline $\begin{array}{l}\text { Cash flow } \\
\text { problem }\end{array}$ & $65.903 \%$ & 0.01 & 0.912 & 2487.882 & 0.000 \\
$\begin{array}{l}\text { Fraudulent } \\
\text { practice }\end{array}$ & $64.083 \%$ & 0.04 & 0.873 & 1921.244 & 0.000 \\
$\begin{array}{l}\text { Nature of } \\
\text { construction } \\
\text { environment }\end{array}$ & $56.382 \%$ & 0.02 & 0.893 & 2128.405 & 0.000 \\
$\begin{array}{l}\text { Technical } \\
\text { performance }\end{array}$ & $64.265 \%$ & 0.01 & 0.871 & 2354.766 & 0.000 \\
\hline
\end{tabular}

Notes: $R$-matrix = Correlation matrix KMO = Keiser-Meyer-Olkin measure of sampling adequacy

\section{Method of Data Analysis}

The data obtained for this study were analysed with warp partial least squarestructural equation modeling software algorithm (Warp PLS-SEM 3.0v). The statistical package is used for the analysis of collected data. The software is one of the powerful software for data analysis and has an advantage of providing $p$ values based on the structure of the research model (Bagozzi and $\mathrm{Yi}$, 1988). responses are encoded and programmed into a system using numbers to represent real data collected, this helps to analyse the data efficiently and effectively (Sekaran and Bougie, 2011; Field, 2009; Giudici, 2003; Oppenheim, 2000) and are entered and run into the warp PLS-SEM software automatically.

\section{DATA ANALYSIS AND RESULTS}

The analysis and discussion of the data obtained for this study are presented as follows:

\section{Model Fit Indices}

A warp PLS-SEM 3.0v algorithm was used in the analysis of the collated data. The collected data were bootstrapped up to 999 times with replacement. The general model fit indices provided three indices: average path coefficient $(A P C)=0.339$ which was significant at $p<0.001$ level of significance, the average R-squared $($ ARS $)=0.671$ which was significant at $p<0.001$ level of significance, and the average variance inflation factor $(\mathrm{AVIF})=1.706$ and was less than 5; this was considered well. The coefficient of determination $R^{2}=0.671$ as shown in Figure 1 . This is regarded as substantial and indicated that $67 \%$ of the variance was explained by the model (Cohen, 1988). 


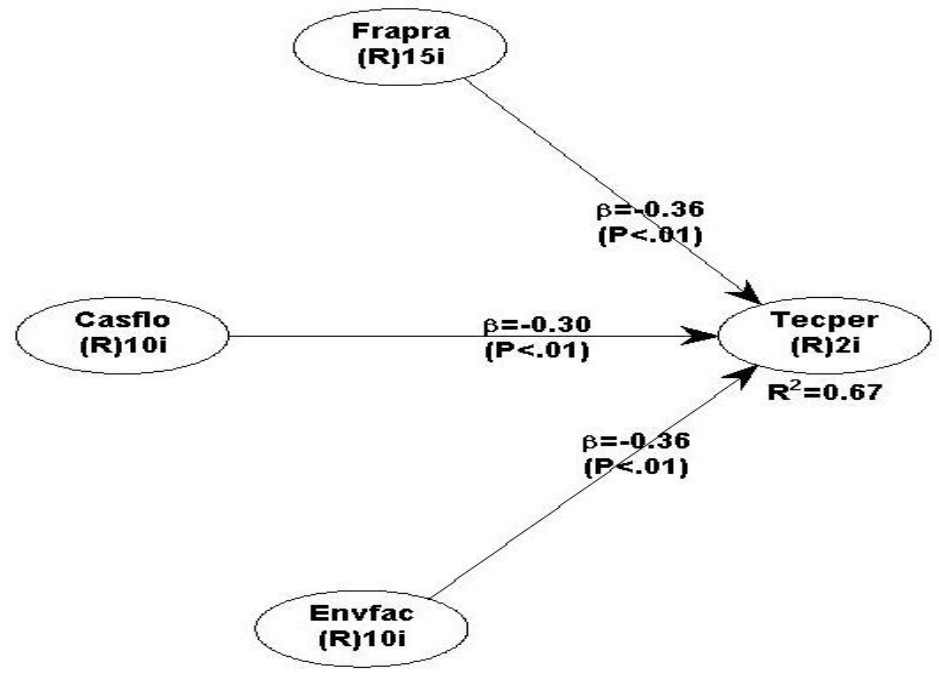

Figure 1. SEM Model for the Relationship between Cost Factors and Technical Performance

\section{SEM Model for the Relationship between Cost Factors and Technical Performance}

Figure 1 presents the structural model for the relationship between cost factors and the technical performance of small size local government projects in Nigeria. The cost factors being the independent constructs comprising of cash flow problem (casflo), fraudulent practice (frapra) and nature of construction environment (envfac). The technical performance of small size local government project (tecper) was the dependent construct. The structural model beta coefficient value between fraudulent practice (frapra) and technical performance of small size local government projects (tecper) was $\beta=-0.36$ at pvalue $<0.01$ which was significant at pralue $=0.05$ level of significance. The structural model beta coefficient between cash flow problem (casflo) and technical performance of small size local government projects was $\beta=-0.030$ at pralue $<0.01$ significant; this was significant at pralue $=0.05$ level of significance. The structural model beta coefficient between nature of construction environment (envfac) and technical performance of small scale local government projects was $\beta=-0.036$ at pvalue < 0.01 which was significant at pralue $=0.05$ level of significance. The structural model indicated that the beta coefficients between the independent constructs and dependent construct were all significant at $p=0.05$ level of significance.

\section{Model Path Coefficients}

Table 5 and Table 6 present the path coefficients of the model and pvalues respectively, the path coefficient between casflo and tecper was $\beta=-0.298$ with a pralue $\leq 0.001$, which indicated that the path was significant at $p \leq 0.05$ level of significance. The path coefficient between effects of frapra in the industry and the 
tecper was $\beta=-0.356$ with a pralue $<0.001$ which was also significant at $p \leq 0.05$ level of significance. The path coefficient between effects of envfac and the tecper was $\beta=-0.362$ with a pvalue $<0.001$ which was significant at $p \leq 0.05$ level of significance. This indicated that casflo problems, effects of frapra and envfac have a negative influence on the tecper of small size projects.

Table 5. Model Path Coefficients

\begin{tabular}{lccc}
\hline & Casflo & Frapra & Envfac \\
\hline Tecper & -0.298 & -0.356 & -0.362 \\
\hline & Table 6. Pvalues Of Path Coefficients & \\
\hline Tecper & Casflo & Frapra & Envfac \\
\hline
\end{tabular}

\section{Standard Errors of the Path Coefficients}

Table 7 presents the standard errors of the path coefficients, the standard error between casflo and tecper was 0.070, then the standard error of the path coefficient between frapra was 0.091 and lastly the standard error for the path coefficient between envfac and tecper was 0.068 .

Table 7. Standard Errors of the Path Coefficients

\begin{tabular}{lccc}
\hline & Casflo & Frapra & Envfac \\
\hline Tecper & 0.070 & 0.091 & 0.068 \\
\hline
\end{tabular}

\section{Effects Sizes for Path Coefficients}

Table 8 present the effect sizes $\left(f^{2}\right)$ for the path coefficients between the independent constructs and the dependent construct. Effect sizes is the change in $R$-squared $\left(R^{2}\right)$ which is explored to see whether the impact of an independent construct on a dependent construct has substantive impact, (f $\left.f^{2}\right)$ and this is automatically computed by the warp PLS-SEM software. The effect size between casflo and tecper was 0.192, which was regarded as medium according to Cohen (1988). The effect size between frapra and tecper was 0.256 , which was regarded as medium according to Cohen (1988). The effect size between envfac and tecper was 0.223 regarded as medium according to Cohen (1988).

Table 8. Effects Sizes for Path Coefficients

\begin{tabular}{cccc}
\hline & Casflo & Frapra & Envfac \\
\hline Tecper & 0.192 & 0.256 & 0.223 \\
\hline
\end{tabular}




\section{Latent Variables Correlations}

Table 9 and Table 10 present the correlations of the latent variables between dependent and independent constructs and their pvalues respectively. In Table 9 the square roots of the average variance extracted (SQRT of AVE) for tecper was 0.759, casflo 0.787, frapra 0.681 and envfac was 0.706 of the square roots of the average variances extracted. This indicated that the square roots of the AVE for the independents and dependent construct are all well above 0.40, which were regarded as adequate (Bagozzi and Yi, 1988; Fornell and Larcker, 1981). The correlation coefficient between tecper and the casflo was $R=-0.642$ significant at $p<0.00$ level of significance. This indicated that cash flow problem had a large negative relationship with technical performance of small size local government projects. The correlation coefficient between tecper and frapra $R=-0.716$ at $p<$ 0.001 level of significance also indicated that fraudulent practice in construction industry had a large negative relationship with technical performance of small size projects. The correlation coefficient between tecper and evfac, $R=-0.592$ at $p<$ 0.001 level of significance further indicated that the nature of construction environment had a large negative relationship with the technical performance of small size local government projects.

The correlations among the independent constructs are likewise strong. The correlation coefficient between casflo and frapra $R=0.656$ which was significant at $p<0.001$ level of significance indicated that fraudulent practice had a large positive relationship with cash flow problem in the Nigerian construction industry. The correlation coefficient between casflo and envfac $R=0.273$ significant at $p<$ 0.001 level of significance this indicated a moderate relationship existed between cash flow problem and the nature of construction environment. The correlation coefficient between envfac and frapra $R=0.391$ significant at $p<0.001$ level of significance also indicated a moderate relationship between the nature of construction environment and the effects of fraudulent practice in the construction industry. The predictive relevance of the model $Q^{2}=0.671$ which is $>0$ and therefore, the model has predictive relevance (Hair et al., 2012).

Table 9. Latent Variables Correlations

\begin{tabular}{lcccc}
\hline & Casflo & Frapra & Envfac & Tecper \\
\hline Casflo & 0.787 & & & \\
Frapra & 0.656 & 0.681 & & \\
Envfac & 0.273 & 0.391 & 0.706 & 0.759 \\
Tecper & -0.642 & -0.716 & -0.592 & \\
\hline
\end{tabular}

Notes: Square roots of average variances extracted (AVE's) shown on diagonal

Table 10. Pvalues for Latent Variables Correlations

\begin{tabular}{lcccc}
\hline & Casflo & Frapra & Envfac & Tecper \\
\hline Casflo & 1.000 & & & \\
Frapra & $<0.001$ & 1.000 & & \\
Envfac & $<0.001$ & $<0.001$ & 1.000 & 1.000 \\
Tecper & $<0.001$ & $<0.001$ & $<0.001$ & \\
\hline
\end{tabular}

102/PENERBIT UNIVERSITI SAINS MALAYSIA 


\section{Cash Flow Problems}

Figure 2 presents a linear graph of the relationships between the tecper of the projects and casflo. The data points and the regression line shows almost straight line sloping from left to right with the coordinate's points $\left(x_{0}, y_{0}\right)$. The coordinate's points lies between $(-2.50,1.70)$ and slopes down to coordinates $(1.40,-0.50)$. This indicated that there is a linear relationship between tecper and casflo. The graph indicates that any increase in casflo problem affects tecper in a negative direction. The reasons for the linear negative relationship between cash flow problem and technical performance of small size local government projects were probably due to the delays in payment of an approved valued works, delays in payments of certified varied works, clients insolvency, etc. These have negative effects on the technical performance of small size local government projects. This is probably due to the small nature of the business and financial reserves of the contractors. The contractors used progress payments to fund the project, delay in payment affects contractor's process of procurements of right plant and equipment for the works and also affects recruitment of qualified and training of staff for any special work. Therefore, cash flow problem affect technical performance of small size local government projects in Nigeria in a negative way.

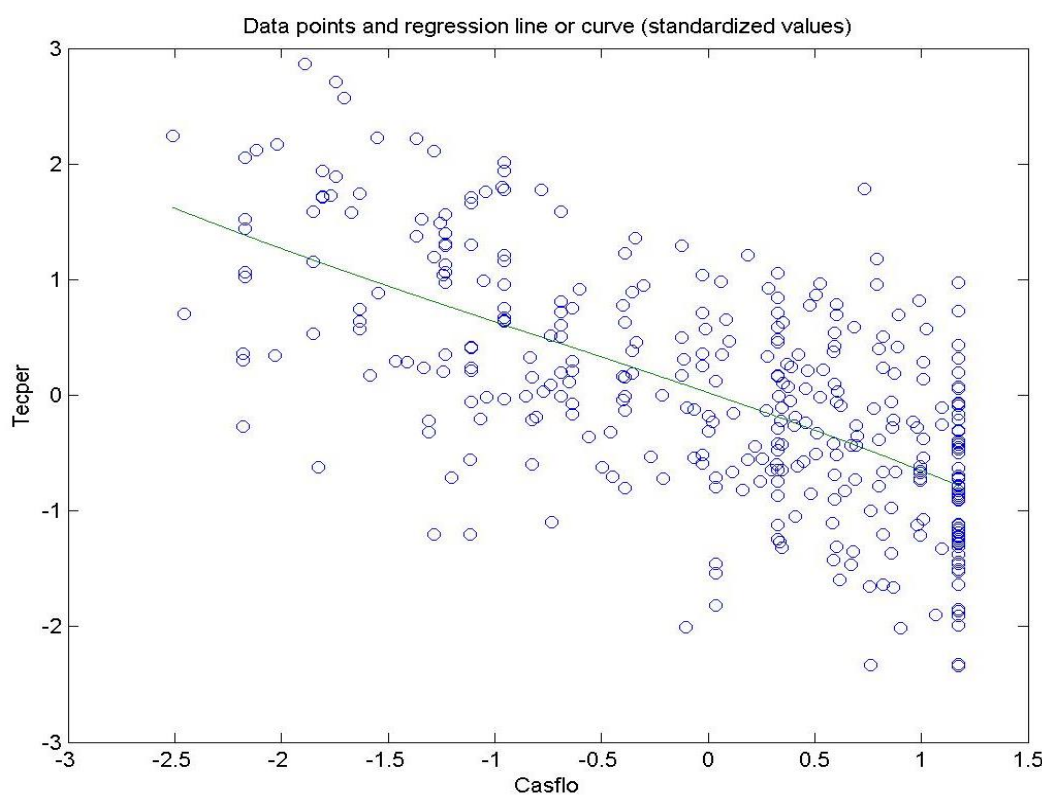

Figure 2. Linear Graph of Tecper and Casflo

\section{Fraudulent Practice}

Figure 3 presents the curvilinear graph of the relationship between tecper and frapra. The coordinate's points and the regression line shows a nonlinear or curvilinear relationship sloping down from left to right hand sides of the graph with 
the coordinates of $(-2.70,2.85)$ then slopes down to coordinates $(1.70,-0.85)$, this indicated that there is a negative curvilinear relationship between tecper and frapra and shows that an increase in frapra factors affects tecper in a negative direction. The reasons for the curvilinear negative relationships between effects of fraudulent practice and technical performance of small size local government projects in Nigeria were as a results of certifying goods without carrying inspections or tests, actions not taken for non-compliance with the terms and condition of contract, falsification of contract document or receipts to get undue advantage or payments, substitutions of specified goods with non-specified ones, etc. These affect the quality of products and in return poor quality performance affects the entire technical performance of products in a negative way.

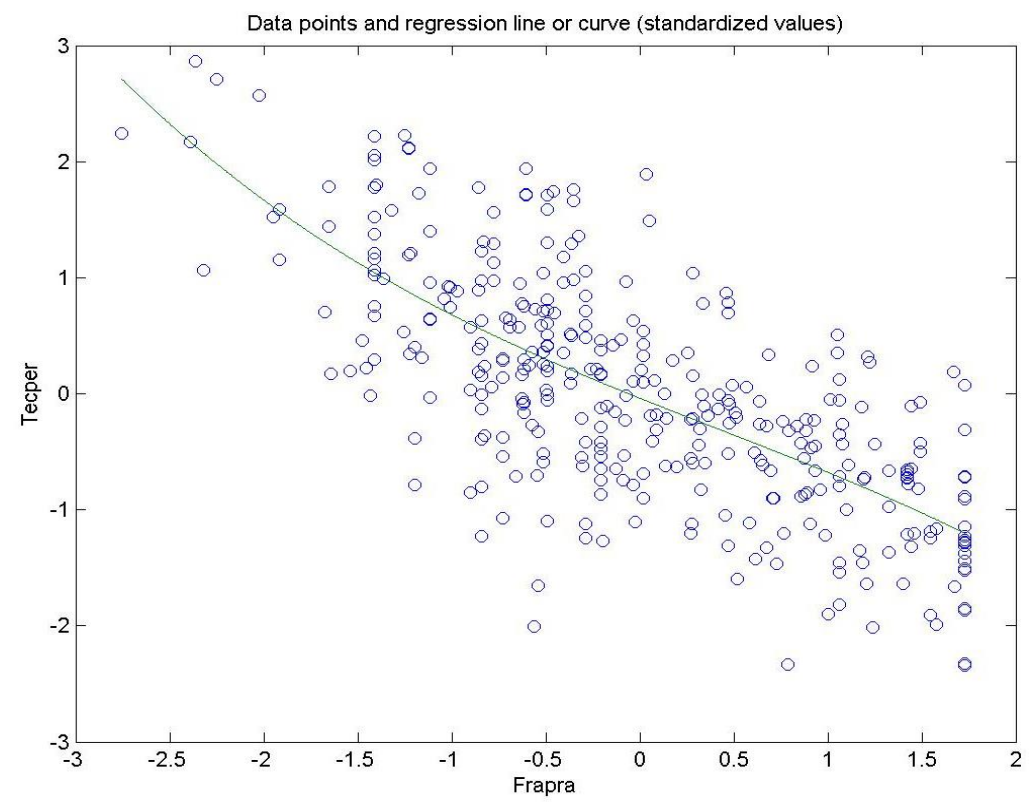

Figure 3. Linear Graph of Tecper and Frapra

\section{Nature of Construction Environment}

Figure 4 presents a warped or doubled curvilinear graph of the relationship between problems of envfac and tecper of projects. The coordinate's points and the regression curve line shows a warped line that slopes down from left to right hand side of the graph, the coordinates were at points $(-3.85,2.30)$ then slopes down to coordinates $(1.10,-0.45)$, which indicated that there is a negative curvilinear or warped relationship between effects of envfac and the tecper of small size local government projects. The reasons for the curvilinear or warped relationship between nature of construction environment and the technical performance of small size local government projects in Nigeria were probably due to the harsh climatic conditions that affect construction materials, frequency in occurrence of civil commotion/disturbances that affects progress of works,

104/PENERBIT UNIVERSITI SAINS MALAYSIA 
presence of surface water that affects concrete and timber during progress of works, effects of storm water that affects works, government regulations and policies that prevent construction activities in certain designated areas etc. These have a negative effect on the speed and quality of products and in turn, affect technical performance of products.

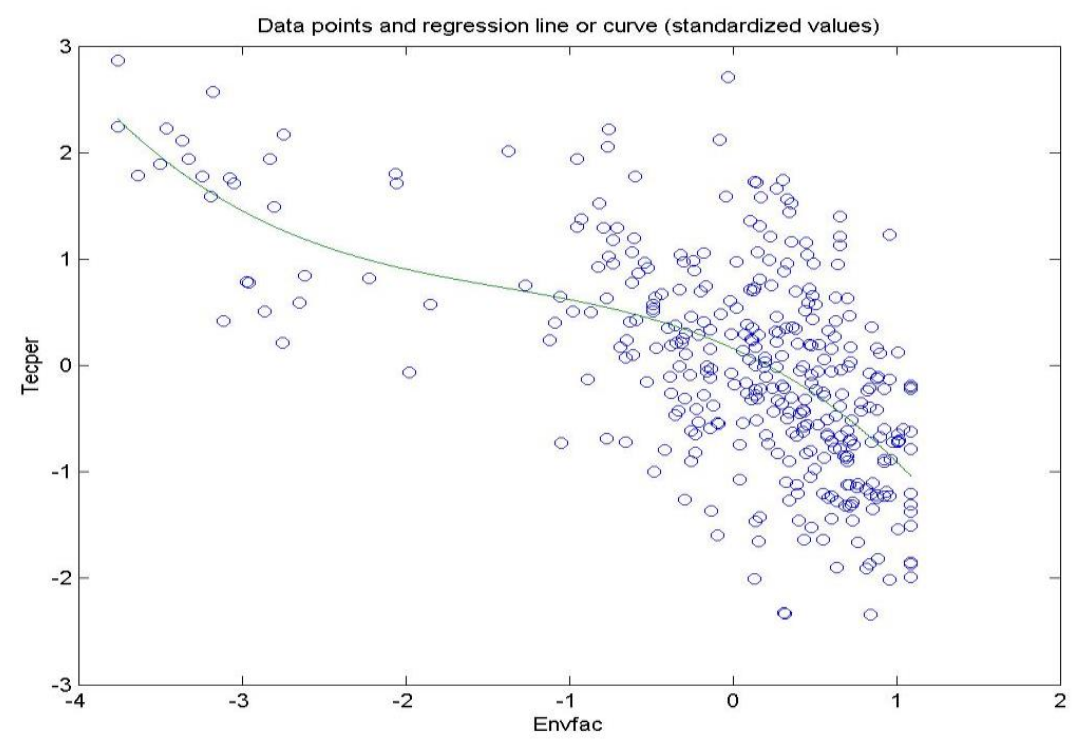

Figure 4. Linear Graph of Tecper and Envfac

\section{DISCUSSION OF THE RESULTS}

Warp PLS-SEM 3.0v was used in achieving the objectives of this study in identifying and assessing the relationship between cost factors that influence the technical performance of small size local government projects in Nigeria. Extensive literature reviews were conducted and the three factors contributing to the poor technical performance of small size local government projects were explored. The factors identified were: cash flow problem, fraudulent practice and nature of construction environment (Ezeh, 2013; Matthew, Patrick and Denise, 2013; Jafari, 2013; Odeyinka, Lowe and Kaka, 2008). The results of the analysis showed that the model path coefficient between cash flow problem and the technical performance of projects was significant. Also, the relationship between cash flow problem and technical performance of the projects revealed a large negative relationship, indicating that cash flow problem affects technical performance of small size local government projects in a negative manner in Nigeria. This is probably that cash flow problem such as late payment for an approved valued works, delayed payment of certified varied works, client insolvency were the major factors affecting technical performance of small size local government projects in Nigeria. The factors affect project technical performance in a quality wise direction such as procurement of right plant and equipment, recruitment and 
training of qualified staff for special works that affect technical performance of local government projects in Nigeria. This finding had confirmed the finding from Luu, Kim and Huynh (2008) and that of Memon et al. (2010) that delayed payments affects quality performance of projects and quality in turn affects technical performance. Similarly, the study was in line with the findings of Liang and Gan (2015) and that of Rusell (2010) that cash flow problem leads to nonprocurement of right plant and equipment for special work. The study contradicts the finding of Ogwueleka (2011) that non-compliance with the innovation culture was the main cause of poor technical performance of projects. The model path coefficient for fraudulent practice was significant. The relationship between fraudulent practice and the technical performance of projects indicated a large negative relationship. This shows that fraudulent practice affects technical performance of small size local government projects negatively in Nigeria. This is probably due to the negative effects of actions not taken for non-compliance with terms and condition of contract, certifying goods without inspections or tests, falsification of contract documents and receipts to get undue advantage or payments: these were major factors affecting technical performance of local government projects in a negative way. This finding confirmed the findings from the study of Matthew, Patrick and Denise (2013) and Elinwa and Buba (1993) that actions not taken for non-compliance with the terms and conditions of contract and kickbacks were the main factors affecting technical performance of projects. While the study of Stevens and Fuentes-George (2015) had a different view probably it was done in developed country US. The third independent construct was the nature of construction environment: the model path coefficient between the nature of construction environment and technical performance of small size local government projects was significant. The relationship between nature of construction environment and technical performance of small size local government projects in Nigeria indicated a large negative relationship. This shows that the nature of construction environment affects technical performance of small size local government projects in Nigeria in a negative direction. This probably due to the negative effects of harsh climatic condition that affects construction materials, effects of civil commotion that affects progress of works and in turn affects quality, presence of surface water that affects concrete and storm water that affects the entire project. These affect products in a negative way. This study confirmed the findings from the study of Akanni, Oke and Akpomiemie (2015) and OSPAR (2008) that the effects of harsh construction environment affect technical performance of projects in developing countries. Therefore the analyses of the model path coefficients in respect to cash flow problem, fraudulent practice and nature of the construction environment had large negative relationships with the technical performance of small size local government projects in Nigeria.

\section{CONCLUSION AND RECOMMENDATIONS}

This study identified and assessed the cost factors affecting technical performance of small size local government projects and the relationship between these factors and technical performance of small size projects. The factors identified were cash flow problem, fraudulent practice, and nature of construction environment. The 
three cost factors (cash flow problem, fraudulent practice and nature of construction environment) had large negative relationships with the technical performance of small size local government projects. The effects sizes of these three independent constructs which affected technical performance of small size local government projects in a quality wise direction were found to be medium or moderate. Whenever the effects of these variables are high, the qualities of the products tend to be low and vice versa. This invariably affects the technical performance of the projects in a negative direction. The study therefore, recommends the practice of incentives/disincentives contract to check out the quality failures of small size projects at local government level and also to create competitiveness among small scale local government contractors for tangible improvements in quality and technical performance of projects. The condition of contract at the local government level should also incorporate penalty clauses against non-adherence to specification, remedial works related to poor technical performances and as well incentivising excellent technical performance. The study further recommends strong penalties and strict deterrent measures for any party in the project involved in any fraud or fraudulent practices. The government should also aim to promulgate appropriate legislation and have the political will in enforcing the law and order in the construction industry.

\section{REFERENCES}

Addo, J.N. (2015). Delay and its effect on the delivery of construction projects in Ghana. African Journal of Applied Research (AJAR), 1 (1): 236-246.

Agostini, L.C., Federico, F.R., Nosella, A.K.C. and Kalantaridis, C. (2015). Does patenting influence SME sales performance?: A quantity and quality analysis of patents in Northern Italy. European Journal of Innovation Management, 18(2): 238-257. doi: 10.1108/EJIM-07-2013-0071.

Akanni, P.O., Oke, A.E. and Akpomiemie, O.A. (2015). Impact of environmental factors on building project performance in Delta State, Nigeria. HBRC Journal, 11 (1): 91-97. doi: 10.1016/j.hbrcj.2014.02.010.

Ali, A., Kamaruzzaman, S., Sulaiman, R. and Cheong, P.Y. (2010). Factors affecting housing maintenance cost in Malaysia. Journal of Facilities Management. 8(4): 285-298. doi: 10.1108/14725961011078990.

Amoah, P., Ahadzie, D.K. and Dansoh, A. (2011). The factors affecting construction performance in Ghana: The perspective of small-scale building contractors. The Ghana Surveyor, 4(1): 41-48.

Bagozzi, R.P. and Yi, Y. (1988). On the evaluation of structural equation models. Journal of the Academy of Marketing Science, 16(1): 74-94. doi: 10.1007/BF02723327.

Brown, J., Loosemore, M., Thomson, D. and Hartmann, T. (2015). Behavioural factors influencing corrupt action in the Australian construction industry. Engineering, Construction and Architectural Management, 22(4): 372-389. doi: 10.1108/ECAM-03-2015-0034.

Chan, A.P.C. and Chan, A.P.L. (2004). Key performance indicators for measuring construction success. Benchmarking: An International Journal, 11 (2): 203221 . 
Cohen, J. (1988). Statistical Power Analysis for the Behavioral Sciences. 2nd Ed. New Jersey: Lawrence Earlbaum Associates Inc.

Doloi, H., lyer, K.C. and Sawhney, A. (2011). Structural equation model for assessing impacts of contractor's performance on project success. International Journal of Project Management, 29(6): 687-695. doi: 10.1016/j.ijproman.2010.05.007.

Doloi, H., Sawhney, A., Iyer, K.C. and Rentala, S. (2012). Analysing factors affecting delays in Indian construction projects. International Journal of Project Management, 30(4): 479-489. doi: 10.1016/j.ijproman.2011.10.004.

Elger, D. (2008). Theory of performances. In Faculty Guidebook: A Comprehensive Tool for Improving Faculty Performance. Sunnyvale, CA: Pacific Crest, 11-14.

Elinwa, A.U. and Buba, S.A. (1993). Construction cost factors in Nigeria. Journal of Construction Engineering and Management, 119(4): 698-713. doi: 10.1061/(ASCE)0733-9364(1993)1 19:4(698).

Ezeh, M.E. (2013). Public procurement reform strategies: Achieving effective and sustainable outcomes. Paper presented at the CIPS Pan Africa Conference. National Theatre, Accra, Ghana, 21-22 May.

Field, A. (2009). Discovering Statistics Using SPSS. London: Sage Publications Ltd.

Fornell, C. and Larcker, D.F. (1981). Evaluating structural equation models with unobservable variables and measurement error. Journal of Marketing Research, 18(1): 39-50. doi: 10.2307/3151312.

Frimpong, Y., Oluwoye, J. and Crawford, L. (2003). Causes of delay and cost overruns in construction of groundwater projects in a developing countries: Ghana as a case study. International Journal of Project Management, 21 (5): 321-326. doi: 10.1016/S0263-7863(02)00055-8.

Gambo, N. and llias, S. (2014). A conceptual framework for improving cost and building contractor performances in developing countries. Paper presented at the 7th International Real Estate Research Symposium (IRERS) 2014. National Institute of Valuation (INSPEN), Selangor, Malaysia, 29-30 April.

Giudici, P. (2003). Applied Data Mining Statistical Method for Business and Industry. London: John Wiley and Sons Ltd.

Hair, J.F., Sarstedt, M., Ringle, C.M. and Mena, J.A. (2012). An assessment of the use of partial least squares structural equation modeling in marketing research. Journal of the Academy of Marketing Science, 40(3): 414-433. doi: 10.1007/s11747-011-0261-6.

Hayes, A.F. (2009). Beyond Baron and Kenny: Statistical mediation analysis in the new millennium. Communication Monographs, 76(4): 408-420. doi: 10.1080/03637750903310360.

Hazır, Ö., Haouari, M. and Erel, E. (2015). Robust optimization for the discrete timecost tradeoff problem with cost uncertainty. In Handbook on Project Management and Scheduling. Vol. 2. Cham, Switzerland: Springer, 865-874. doi: 10.1007/978-3-319-05915-0_9.

He, Q., Luo, L., Hu, Y. and Chan, A.P.C. (2015). Measuring the complexity of mega construction projects in China: A fuzzy analytic network process analysis. International Journal of Project Management, 33(3): 549-563. doi: 10.1016/j.jproman.2014.07.009.

108/PENERBIT UNIVERSITI SAINS MALAYSIA 
Hulland, J. (1999). Use of partial least squares (PLS) in strategic management research: A review of four recent studies. Strategic Management Journal, 20(2): $\quad 195-204 . \quad$ doi: $10.1002 /(\mathrm{SICI}) 1097-0266$ (199902)20:2<195::AIDSMJ13>3.0.CO;2-7.

Inuwa, I.I., Usman, N.D. and Dantong, J.S.D. (2015). The effects of unethical professional practice on construction projects performance in Nigeria. African Journal of Applied Research (AJAR), 1 (1): 72-88.

Jafari, A. (2013). A contractor pre-qualification model based on the quality function deployment method. Construction Management and Economics, 31 (7): 746-760. doi: 10.1080/01446193.2013.825045.

Kshetri, N. (2015). Success of crowd-based online technology in fundraising: An institutional perspective. Journal of International Management, 21 (2): 100 116. doi: 10.1016/j.intman.2015.03.004.

Kurul, E., Zhou, L. and Keivani, R. (2013). Sustainability performance measurement framework for PFI projects in the UK. Journal of Financial Management of Property and Construction, 18(3): 232-250. doi: 10.1 108/JFMPC-08-2012-0032.

Liang, Y. and Gan, S. (2015). Empirical study on institutional investors, free cash flow and corporate performance. Paper presented at the 2015 International Conference on Education Technology, Management and Humanities Science (ETMHS 2015). Xian, Shaan, China, 21-22 March. Amsterdam: Atlantis Press. doi: 10.2991/etmhs-15.2015.61.

Local Government Monitoring and Evaluation Committee (LGMEC). (2009). Monitoring of local government projects. Bauchi, Nigeria: 2008-2009 Report. Bauchi, Nigeria: LGMEC.

LuU, V.T., Kim, S. and Huynh, T. (2008). Improving project management performance of large contractors using benchmarking approach. International Journal of Project Management, 26(7): 758-769. doi: 10.1016/j.ijproman.2007.10.002.

Mahesh, M.G. (2012). Study of the factors affecting labour productivity at a building construction projects in USA: Web survey. MSc diss. North Dakota State University of Agriculture and Applied Science.

Matthew, K., Patrick, K. and Denise, K. (2013). The effects of fraudulent procurement practices on public procurement performances. International Journal of Business and Behavioural Sciences, 3(1): 17-27.

Memon, A.H., Ismail, A.R., Ade Asmi, A.A. and Nor Hazana, A. (2013). Using structural equation modelling to assess effects of construction resource related factors on cost overrun. World Applied Sciences Journal, 21 (5): 6-15. doi: 10.5829/idosi.wasj.2013.21.mae.9995.

Memon, A.H., Ismail, A.R., Mohd Razaki, A. and Ade Asmi, A.A. (2010). Factors affecting construction cost in Mara large construction project: Perspective of project management consultant. International Journal of Sustainable Construction Engineering and Technology, 1 (2): 41-54.

Mohit, M.A., Ibrahim, M. and Rashid, Y.R. (2010). Assessment of residential satisfaction in newly designed public low-cost housing in Kuala Lumpur, Malaysia. Habitat International, 34(1): 18-27. doi: 10.1016/j.habitatint.2009.04.002.

Mortimer, D. and Mortimer, S.T. (2015). Quality and Risk Management in the IVF Laboratory. Cambridge: Cambridge University Press. doi: 10.1017/CBO9781139680936. 
National Population Commission. (2000). Nigeria Demographic and Health Survey 1999. Calverton, MD: National Population Commission and ORC/Macro.

Ngacho, C. and Das, D. (2015). A performance evaluation framework of construction projects: Insights from literature. International Journal of Project Organisation and Management, 7(2): 151-173. doi: 10.1504/IJPOM.2015.069616.

Odeyinka, H.A., Lowe, J. and Kaka, A. (2008). An evaluation of risk factors impacting construction cash flow forecast. Journal of Financial Management of Property and Construction, 13(1): 5-17. doi: $10.1108 / 13664380810882048$.

Ogwueleka, A. (2011). The critical success factors influencing project performance in Nigeria. International Journal of Management Science and Engineering Management, 6(5): 343-349.

Oppenheim, A.N. (2000). Questionnaire Design, Interviewing and Attitude Measurement. New York: Continuum International Publishing Group.

Oslo and Paris Conventions for the Protection of Marine Environments (OSPAR) Commission. (2008). Background Document for the EcoQo on Plastic Particles in Stomach of Sea Birds. London: OSPAR Commission.

Oyewobi, L.O. and Ogunsemi, D.R. (2010). Factors influencing reworks occurrence in construction: A study of selected building projects in Nigeria. Journal of Building Performance, 1 (1): 1-20.

Pallant, J. (2010). SPSS Survival Manual: A Step By Step Guide to Data Analysis Using SPSS. Berkshire, UK: Open University Press.

Qu, Y., Liu, Y., Nayak, R.R. and Li, M. (2015). Sustainable development of ecoindustrial parks in China: Effects of managers' environmental awareness on the relationships between practice and performance. Journal of Cleaner Production, 87: 328-338. doi: 10.1016/j.jclepro.2014.09.015.

Roldán, J.L. and Sánchez-Franco, M.J. (2012). Variance-based structural equation modeling: Guidelines for using partial least squares in information systems research. In M. Mora, O. Gelman, A. Steenkamp and M. Raisinghani (eds.). Research Methodologies, Innovations and Philosophies in Software Systems Engineering and Information Systems. Hershey, PA: Information Science Reference, 193-221. doi: 10.4018/978-1-4666-0179-6.ch010.

Russell, H. (2010). Cash Flow Problems in a Business. Available at: http://www.smallbusiness.chron.com/cash-flow-problems-business4916.html.

Sambasivan, M. and Soon, Y.W. (2007). Causes and effects of delays in Malaysian construction industry. International Journal of Project Management, 25(5): 517-526. doi: 10.1016/j.jproman.2006.11.007.

Samuel, E.I. and Ovie, A.I. (2015). Iterating a stationary cause of cost overruns in construction projects. International Journal of Construction Engineering and Management, 4(2): 52-59.

Sekaran, U. and Bougie, R. (2011). Research Methods for Business: A Skill Building Approach. New Jersey: John Wiley and Sons Ltd.

Songer, A.D. and Molenaar, K.R. (1997). Project characteristics for successful public-sector design-build. Journal of Construction Engineering and Management, 123(1): 34-40. doi: 10.1061/(ASCE)0733-9364(1997) 123:1 (34). 
Stevens, C. and Fuentes-George, K. (2015). The Green Economy as an opportunity to improve US biodiversity assistance. In A. Gasparatos and K.J. Willis (eds.). Biodiversity in the Green Economy. Abingdon, UK: Routledge, 360.

Takim, R. and Akintoye, A. (2002). Performance indicators for successful construction project performance. In D. Greenwood (ed.). Proceedings: 18th Annual ARCOM Conference. Vol. 2. Newcastle, UK: Association of Researchers in Construction Management, 545-555.

Team Leadership. (2010). The Five Levels of Teams: Where are You on the Team Curve? Part 3. 26 February. Available at: http://www.changingwinds. wordpress.com/2010/02/26/the-five-levels-of-teams-where-are-you-on-theteam-curve-part-three-of-a-series/.

Vilanova, M.R.N., Filho, P.M. and Balestieri, J.A.P. (2015). Performance measurement and indicators for water supply management: Review and international cases. Renewable and Sustainable Energy Reviews, 43: 1-12. doi: 10.1016/j.rser.2014.11.043.

Wasi, D. and Skitmore, M. (2001). Factors affecting the performance of small indigenous contractors in Papua New Guinea. Australasian Journal of Construction Economics and Building, 1(1): 80-90. doi: 10.5130/ajceb.v1il.2282.

Winch, G.M. (2010). Managing Construction Projects. New Jersey: John Wiley and Sons Ltd.

Xiao, H. and Proverbs, D. (2002). The performance of contractors in Japan, the UK and the USA: An evaluation of construction quality. International Journal of Quality and Reliability Management, 19(6): 672-687. doi: $10.1108 / 02656710210429564$.

Yasamis, F., Arditi, D. and Mohammadi, J. (2002). Assessing contractor quality performance. Construction Management and Economics, 20(3): 211-223. doi: 10.1080/01446190110113693. 